\title{
金属切削・研削剤としての応用
}

\author{
後藤 健一 \\ 日本大学生産工学部 (千葉県習志野市泉町 1-2-1)
}

\section{Application of Surfactants for a Cutting or Grinding Agent of Metal}

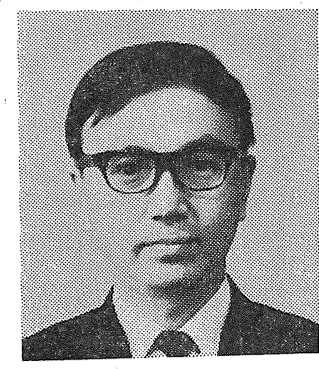

\author{
Kenichi Goт̄̄ \\ College of Industrial Technology Nihon University (Izumi-cho, Narashino-shi)
}

\section{1 ま え がき}

最近の金属切削，研削，ドリリングなどの加工には潤 滑, 減摩, 冷却などの目的で各種の油剤が使用され, 界 面活性剂の応用が広範囲にわたっている。たとえば，極 圧添加剤, 油性向上剂, サビ止め剤, 酸化防止剤などは 主として不水溶性油剤で問題になり, 乳化剂, カップリ ング剂, 消ホウ剂, サビ止め剤, 殺菌郕, 酸化防止剤, 油性向上剤などは水溶性油剤で広く応用されている。

JIS K 2241-1961 によれば，切削，研削油剤は成分的 分類によって, 不水溶性と水溶性の各種に細分類され, 規定されている。すなわち，

1）不水溶性切削油剂

極圧添加剤は，イオウ系，塩素系，硫塩化系，リン采 やこれらの混合物などで，非常に不安定な化合物でわず かな熱によっても分解する活性なものと，分解しにくい 不活性なものとがあるが，工具刃先が被削材を切削して いる高温極圧部や切クズが工具刃先へ溶着する部分でイ オウや塩素を分離し，これが被削材と工具摩擦面とに化 合して潤滑作用をなし，構成刃先の防止による工具寿命 の延長や仕上精度の向上，減摩作用，冷却作用などの効 果を与えるものである。この極圧添加片を含有しないも のを JIS では 1 種と呼び，含有するものを 2 種と呼ぶ が, 1 種はさらに鉱油のみの 1 号と, 油脂類と鉱油の混合 油をその油脂分\%と粘度で使用目的別に 2 号と 3 号に分 けている。2 種の極圧添加剤は, イオウの $100^{\circ} \mathrm{C} 1 \mathrm{hr}$ に よる腐食状態で活性と不活性に分け, 2 種 1 4 号 (不活 性形) と 2 種 5 8 号 (活性形) とに分けている。この 細分類は, 脂肪油分, 極圧剂含有量, 粘度, 作業目的な どによっている。概して，鉱油を硫化したものが活性形 で, 油脂類を硫化したものが不活性形であるとしてい る。

2) 水溶性切削油剤

成分と性状により W 1 種 (エマルション形), W 2
種 (ソリューブル形), W 3 種 (ソリューション形) に分類され, 界面活性剤の応用が最も著しい油剤であ る。

$\mathrm{W} 1$ 種（エマルション形）：水に溶かすと乳白色の O/W 形エマルションとなるもので，組成は主として鉱 油を基油とし, 乳化剂として石油スルホン酸塩, 硫化 油, 各種セッケンなどを用いたもので，このほか水と油 の可溶化を助けるためのカップリング剤としてアルコー ル類および水などを含むものである。一般に潤滑性が， W 2, 3 に比べて良いが, 硬水には不適で安定性, 耐腐 敗性に劣る。この改善には, 消ホウ剤, サビ止め剂, 殺菌 剤, 酸化防止剂, 油性向上剂を含有させたものがある。 使用倍率は 10 30 倍と他の W 2, 3 亿比して小さい。低 速重切削を除く一般切削および研削に応用され，おもな 効果は工具寿命の向上であるといわれる。

$\mathrm{W} 2$ 種 (ソリューブル形)：陰イオン界面活性剂, 非 イオン界面活性剤の含量が多くエマルション形に比し希 釈倍率を大にして使用しても透明または半透明に分散し て使用できるものである。切削の場合で 20 50 倍, 研 削で 50 100 倍にも使用されている。仕上面精度を要す る研削, 高熱の出るドリングなどに効果がある。界面活 性剂を多量に含有するため硬水に使用でき，使用倍率む 高い，W1 種で述べたような添加郕はもちろん使用さ れる。一般切削, 研削に応用され, おもな効果は仕上面 向上であるといわれる。

$\mathrm{W} 3$ 種 (ソリューション形) : 前 2 者と異なった考光 のもとに組成が成り立っている。すなわち，亜硝酸ナト リウム,クロム酸ナトリウムなどの無機塩類および有機 アミンを主体とするもので, 水に溶けて溶液となり透明 である [一部，界面活性剤を含むもの（1号）もあるの で完全な溶液とはいえないが］。このものは無機塩類の 金属表面に対するイオン吸着を切削効果の特徴とするう え, $\mathrm{NaNO}_{2}$ などはパッシベータとして働き，またアミ ンとの共同作用によりサビ止め効果を向上させたもので 
ある。一般に老化が少なく，腐敗しないのが特徵で，50 〜100 倍にして研削に用いられる。おもな効果は研削能 率の向上である。

以上は JIS からの引用であり，本邦産油剤のある範 囲のものはこれにのっとっている場合が多いと思われる が，諸外国で使用されている油剤配合を調べてみると JIS の規定で律することのできないさまざまの配合が工 夫されている。そこで，本文にはまずその一部を紹介し てみたいと思う。

\section{2 切削油剂に必要な性質と油剂配合例}

切削油剤に要求される一般的性質には，1）切削性を よりよくする性質, 仕上面の精度をよりよくする性質, 工具寿命をよくする性質 (主として潤滑作用, 冷却作用 の良否によって決定されるが，別の観点からは構成名 の制御作用，切クズ工具接触長さ抑制作用などの性質が 要求される)。2) 被削材および工作機械をさびさせな 、性質, 発煙, 霧散のより小さな性質, 安定性 (分離, 層状にならないことと老化しない性質)，人体に対して 無害である性質（悪臭のないことを含む），塗料を侵さ ない性質, などがある。

これまで知られている切削, 研削油剤は実に多数のも のがあるが，不水溶性と水溶性とに分けて，実用上の最 近の油剤配合例を記載してみよう。

\section{$2 \cdot 1$ 不水溶性切削油}

釷油や脂肪油に極圧添加剂を加えたり, 保存安定性, 希 勫安定性, 防食性, 油性向上, 臭気改善, 透明性, アワ立 ち防止などの性質を与えるための添加剤の配合など, 種 々の工夫が行なわれてきている。その事例をあげると，

$2 \cdot 1 \cdot 1$ 金属切削油 ${ }^{11}$ イオウ $20 \sim 10 \%$ とロジン 80 〜90\%からなる切削油, カッターに油がよく付くように するためにセッケン，ステアリン，鉱油などを加える。 たとえば，ロジン 20〜27\%，ステアリン 25 20\%，イ オウ $5 \sim 3 \%$, 鉱油 10 15\%, セッケン 40 35\% に配 合する例がある。

$2 \cdot 1 \cdot 2$ ナフテン系鉱油で活性イオウを含む切削油 ${ }^{23}$ ナフテン系釷油で vp $260 \sim 405^{\circ} \mathrm{C}$, 流動点 $-34^{\circ} \mathrm{C}$ の のを $\mathrm{H}_{2} \mathrm{SO}_{4} 1 \%$ (vol) と室温で $90 \mathrm{~min}$ かきまぜて $4 \mathrm{hr}$ 静置したのち，残りかすを分離し，ベントナイト $1 \%$ (wt) と接触させて中和し，口過した油を得る。この酸 処理油 $700 \mathrm{~g}$ と $\mathrm{S}_{2} \mathrm{Cl}_{2} 300 \mathrm{~g}$ を空気を吹き込み反応さ せ, 反応終了後, 全イオウ $13 \%$ のうち活性イオウ 12.8 \%を含む油を得る。この油を鉱油で約 3 倍に薄めて切削 油として使う。

$2 \cdot 1 \cdot 3$ ナフテン系鉱油のスルホン化 ${ }^{3)}$ 前者と類似 のものであるが，ナフテン系鉱油（粘度 180 セイボルド 秒 $37.7^{\circ} \mathrm{C}$ )を $98 \%$ の $\mathrm{H}_{2} \mathrm{SO}_{4} 12 \%(\mathrm{wt})$ とスルホン化 し, 酸の残りかすを除去する。油層をさらに $45^{\circ} \mathrm{C}$ で 1.2
\% wt のイオウで硫化し， $\mathrm{Ca}(\mathrm{OH})_{2}$ 液で中和し， $77^{\circ} \mathrm{C}$ で空気吹込み乾燥を行なうが，このようにして得た油は スルホン化または硫化の段階をオミットした場合より耐 荷重性が良くなるということである。

$2 \cdot 1.4$ 硫化切削油の保存拉よび希釈安定化 ${ }^{4}$ 硫化 切削油の経時变化, 保存安定性, 希釈安定性の改善のた めオキシステアリン酸エステルを使ら。 $\alpha$ または $\beta$-オ キシステアリン酸かまたは，10，11 または 12-オキシス テアリン酸が用いられる。たとえば，鉱油 95 部をメチ ル-12-オキシステアリン酸 5 部と加熱しイオウ華 15 部 を混合し，均一にして保存するが，使用時には 100 200 \% (wt) の鉱油に薄めて使用する。エステルとしてオキ システアリン酸ブタノールエステルを $5 \%$ 使ら場合もあ る。

2.1 .5 酸化石油からの切削油 $\left.{ }^{5}\right)$ 酸化石油 $\left(37.7^{\circ} \mathrm{C}\right.$ で 75 150 セイボルド秒の粘度, ケン化価 55 ８， 中 和価 12 25) に $\mathrm{S}_{2} \mathrm{Cl}_{2}$ または $\mathrm{SCl}_{2}$ を反応させるが, たとえば酸化石油 $400 \mathrm{~g}$ と $\mathrm{S}_{2} \mathrm{Cl}_{2} 66.8 \mathrm{~g}$ を混合し, $\mathrm{HCl}$ の放出がとまるまでかきまぜ, $48 \mathrm{hr}$ 静置したのち空気 吹达みを $18 \mathrm{hr}$ 行ない, 残りかすを除去し, $\mathrm{Ca}(\mathrm{OH})_{2}$ で中和する。パラフィン油 $\left(37.7^{\circ} \mathrm{C}\right.$ で 100 セイボルド 秒の粘度）にこの中和生成物を $20 \%$ 溶かすと, 全イオ ウ $1.64 \%$, 遊離イオウ $0.63 \%$ で仕上面がなめらかで, 摩耗も少なくなつた。

$2 \cdot 1 \cdot 6$ ポリサルファイド系添加剂を加えた切削(油6) ジメチルベンジルクロリド 27 部， Na-テトラサルファ イド $40 \%$ 水溶液 52 部, ジーゼル油 21 部の混合物を $92^{\circ} \mathrm{C}$ で $2 \sim 4 \mathrm{hr}$ かきまぜて, 分離したジメチルベンジル ポリサルファイドを $3.08 \mathrm{~g}$ にイオウを $154 \mathrm{~g}$ 加える。 これを $134^{\circ} \mathrm{C}$ で $2.5 \mathrm{hr}$ かきまぜて, ジメチルベンジル ペンタサルファイドを得る。これを 1 〜 5\% 鉱油に添加 して切削油とする。

$2 \cdot 1 \cdot 7$ 八ロゲン系極圧添加剤を含む切削油 ${ }^{7}$ 脂肪 族, 芳香族, 脂環式化合物系の炭化水素の塩素またはフ ッ素化合物，たとえばヘキサクロルブタジエンとか塩素 化ビフェニルを添加剤とする。 $\mathrm{Cl}$ または $\mathrm{F}$ を含むビフ ェニル（全八ロゲン含有量約 45\%) を1部，4-クロルフ ェニルホフィニック酸を 1 部, 鉱油（エングラー粘度 $5 \sim 6^{\circ}\left(50^{\circ} \mathrm{C}\right)$ ) 200 部配合して切削油を作る。

$2 \cdot 1 \cdot 8$ 塩素系極圧添加鼡を含む切削油 ( $^{8}$ 八ロゲン 化ケイ酸エステルまたはそれらの重合同族体の有機含リ ン化合物の混合物で $-\mathrm{P}(\mathrm{R}) \mathrm{X}$ または $\mathrm{P}(\mathrm{R}) \mathrm{X}$ の形のも

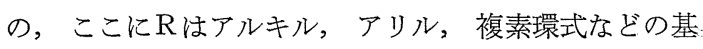
で, Xは $\mathrm{OH}, \mathrm{SH}, \mathrm{OR}, \mathrm{SR}, \mathrm{NH}_{2}, \mathrm{NHR}, \mathrm{NR}_{2}$ などであ るが，これらは切削油添加剤として有効である。配合例: としては，テトラビス（クロルェチル）シリケートを 1. 部, ジブチルー4-クロルフェニルホスホネートを1部, 鉱油 198 部を $50^{\circ} \mathrm{C}$ でよく混合し，切削油とする。 
$2 \cdot 1 \cdot 9$ クロレンディック酸のジエステルを含む切削 油と極圧潤滑油 ${ }^{9}$ クロレンディック酸ジブチルエス テルを鉱油に $14 \%$ 添加したものは，低切削速度で良好 な表面仕上げが必要なときに適した切削油となる。クロ レンディック酸無水物 $(1,4,5,6,7,7$-ヘキサクロル・ビ

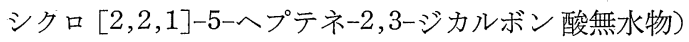
を $371 \mathrm{~g}$ とブタノール $300 \mathrm{~g}$ と $p$-トルエンスルホン酸 $2.5 \mathrm{~g}$ を配合し, 過剰のブタノールを除去したもの使用 する。

$2 \cdot 1 \cdot 10$ イオウ，塩素を極圧添加剤として含む切削 油 $^{10)}$ 硫化油（0.3〜2\% のイオウを含む潤滑油留分） を 80〜99\%,ソルビタンモノまたはトリオレエートを 1〜20\%, 油溶性塩素化有機化合物（塩素化ビフェニ ル，ジフェニルオキシドとパラフィンロウよりなる）を 0.25〜 5\% 配合した切削油である。その代表的組成とし て, 硫化油を $29 \%$ 加えた粘度 100 セイボルド秒 (37.7 $\left.{ }^{\circ} \mathrm{C}\right)$ の中質油とイオウ $0.8 \%$ ，ソルビタンモノオレェー トを $5 \%$, それに $1.62 \%$ の $\mathrm{Cl}$ を含む塩素化ビフェニ ルを $3 \%$ 配合したものがある。

$2 \cdot 1 \cdot 11$ 不水溶性切削油の防食添加剂配合例 ${ }^{11)}$ (3) 切削油剂とくに鈗油と硫塩化ピネンからなる切削油の腐 食性と混濁性は 0.03 0.6\% (wt) のマホガニー石油ス ルホン酸バリウムの添加で抑制できる ${ }^{11)}$ 。また,極圧添加 剂として活性のイオウと塩素を含む切削油が腐食性を与 えるのを防ぐために，イソプロピルオレエートとポリオ キソアルミニウム・オレエートの等量混合物の $1 \%(\mathrm{wt})$ を，硫塩化脂肪 $8 \%$ と潤滑油 $91 \%$ の混合物に添加した ところ，未添加のものは腐食がひどかったが，添加した 油剂は $24 \mathrm{hr}$ 後も切削面に腐食を生じなかった ${ }^{12)}$ 。なお 塩素化炭化水素を 2 35\% 含む切削油剂の被切削金属面 に対する腐食性を抑制するのにナフテン酸鉛 $5 \%$ を添加 して効果があったという例もある ${ }^{13)}$ 。

$2 \cdot 1 \cdot 12$ 透明な切削油 ${ }^{14), 15)}$ ヒマシ油またはリシノ レイン酸を灰汁または $\mathrm{KOH}$ で完全に清澄になるまで処 理して得られる切削油 ${ }^{14)}$ あるいは鉱油にモノクロルフェ ニル・ジメチル・ホスホロチオネートを $0.5 \sim 15 \%$ 添加 すると潤滑性のよい透明な切削油を得る ${ }^{15)}$ 。

$2 \cdot 1 \cdot 13$ 油性と臭の改善 ${ }^{16)}$ 油性と臭気を改善する 混合物として，1,2,4-トリクロルベンゼン $900 \mathrm{~g}$ とミリ スチン酸エチル $80 \mathrm{~g}$ とカプリン酸エチル $20 \mathrm{~g}$ の混合物 を鉱油に添加すると良い。

$2 \cdot 1 \cdot 14$ 極圧添加剤を含む切削油のアワ立チ抑制剂 ${ }^{17)}$ イオウや塩素を極圧添加剤として含む切削油のアワ立チ 性を抑制するにはアルケニルコハク酸エステル誘導体を 0.05〜0.5\%(vol)添加すると有効といわれている。この ものはアルケニルコハク酸とグリコール (炭素数 2〜4) とのエステルの混合物である。配合例として鉱油にテト ラプロペニルコハク酸無水物 $(0.6 \mathrm{~mol})$ と $0.6 \mathrm{~mol} の$
水を加え, $82^{\circ} \mathrm{C}$ で無水物を加水分解したものがある。

$2 \cdot 2$ 水溶性切削油剤（エマルション形，ソリューブ ル形, ソリューション形)

2・2・1 Mid-Continent Oil のエマルション形切削油 剤 $^{18)}$ Mid-Continent Oil は潤滑油抽出の際にフェノ ールで処理されたもので，マホガニースルホネート系の 乳化㓮で安定な $\mathrm{O} / \mathrm{W}$ 形のエマルションを作る。この乳 化㶡の組成はマホガニースルホネートを 10.06 部，カッ プリング剤のジェチレングリコールを 1.64 部, 油の分 散性をコントロールするオレイン酸と $\mathrm{KOH}$ はそれぞれ 2.01 部と 0.34 部，それに水を 0.95 部配合したもので ある。希釈倍率は 10 倍〜20 倍である。

$2 \cdot 2 \cdot 2$ アルカノールアミン塩を使ったエマルショ ン ${ }^{19)}$ 石油スルホン酸ナトリウムに加えてアルカノー ルアミン塩を配合してもエマルション形の切削油剤とし て良く，その配合は，鉱油（粘度 130 セイボルドュニバ 一サル秒 $\left.37.7^{\circ} \mathrm{C}\right) 84.5 \%(\mathrm{wt})$, 油溶性石油スルホン酸 ナトリウム（ドライベース） $4.7 \%$ ，トール油精製品のト リエタノーノルアミンセッケン $6.0 \%$ ，ナフテン酸トリ エタノールアミン $3.0 \%$, エタノール $0.9 \%$, 水 $0.9 \%$ というものである。

$2 \cdot 2 \cdot 3$ パラフィン系ワックス油のエマルション ${ }^{20)}$ 融点 $70^{\circ}$ 以上の石油残留分から得られるパラフィン系の ワックス性油でその $80 \%$ が直鎻パラフィン系炭化水素 のもの $\left(\mathrm{mp} 82 \sim 5^{\circ} \mathrm{C}\right)$, その一部はハロゲン化されてい る。これに油溶性脂肪酸やリン酸塩を一部添加する。配 合例として，パラフィンロウ $33 \%$ ，ソルビタンモノス テアレート $4 \%$, ソルビタンモノステアレートのポリオ キシェチレン誘導体 $4 \%$, ジドデシルホスフェート 1.5 $\%$, 水 $57.5 \%$ がある。

$2 \cdot 2 \cdot 4$ ナフテン酸抽出用 Napex 液からのエマルショ ン ${ }^{21)}$ 潤滑油からナフテン酸の抽出に用いる Napex 溶液からエマルション形切削油剤が作られる。このもの の組成はトルエンまたはキシレンのスルホネートを 20 〜30\%, $\mathrm{Na}_{2} \mathrm{SO}_{4} 10 \sim 15 \%, \mathrm{NaOH} 0.5 \sim 5 \%, \mathrm{H}_{2} \mathrm{O} 50$ 〜 70\% の水溶液である。潤滑油(粘度 45 セイボルド秒, $\left.98^{\circ} \mathrm{C}\right)$ を $79.4 \%$ (wt), Napex 15.6\%, ジェチレングリ コール $3.0 \%$, トリェタノールアミン $1.0 \%$, 水 $1.0 \%$ でエマルションを作る。

$2 \cdot 2 \cdot 5$ 豚脂の蒸留分を使ったエマルション ${ }^{22)}$ 高級 脂肪族アシルおよびアセチル基をもつグリセリド，たと えば豚脂の蒸留から得られるモノグリセリドを $50 \%$ (wt)，これにラウリル硫酸ナトリウム $0.8 \%, \mathrm{NaNO}_{3}$ と $\mathrm{NaNO}_{2}$ の混合物 $1 \%$ ，水 $48.2 \%$ を配合してェマルシ ョンにすると切削油剤とし使用できる。

$2 \cdot 2 \cdot 6$ チタン合金など特殊被削材用の切削油剂 ${ }^{23) ~ 25) ~}$ チタニウムやその合金などは硬くて切削しにくい材料で あるが，これらの場合には，石油スルホン酸バリウム 5 
〜20\%(vol), 石油スルホン酸ナトリウム 20\%,グリコー ル (カップリング剤) 1\%，ペール油 59〜74\% の配合物 1 部に 10 倍量の水を加えてエマルションにすると効果 的であるといわれる ${ }^{23)}$ 。また，チタニウムやステンレス 鋼に有効な油剂として, トリアルキル亜リン酸塩および チオ亜リン酸塩などのアルキル基の炭素原子数が 6 10 のものを1 15\% 添加すると良いという報告があり， ト リーnーオクチル・チオホスフィット $85 \%$ とリノール酸 15 \%の配合をこれらのかたい材料のドリリングに使用して 有効であったといら ${ }^{24)}$ 。同様に，チタニウムの研摩や航 空機用特殊鋼などの高度の表面仕上に使用されるエマル ション形研削油剤として, 硫化マッコウ鯨油 (マッコ ウ油 70\%，鉱油 16\%，イオウ 14\%) を14 部(vol)を 鉱油 64.5 部之混合し, いったん $32.3^{\circ} \mathrm{C}$ 亿予熱し, 冷 却後, ロジン酸, 脂肪酸セッケン $47 \%$, クレジル酸 19 $\%$, 水 $9 \%$, 石油スルホン酸塩 $5 \%$, 鉱油 $20 \%$ からな る混合物 21.5 部とよく混ぜて, 以上のものを 10 倍の 水で薄めて適当なエマルションにすると有効といわれ $3^{25)}$ 。

$2 \cdot 2 \cdot 7$ 殺菌剤, バクテリヤ抑制剤を含むエマルショ ン26) 29) 切削油剂がバクテリヤや細菌のために分解し 劣化することを防ぐ各種の添加剤が使用されているが， フェニル塩化水銀の $0.005 \sim 0.01 \%$ とトリクレゾールの $0.002 \%$ とを組み合わせて殺菌した例がある。なおこの 油剤は, 鉱油, 高級脂肪酸のジおよびトリエタノールア ミンセッケン，スルホン化ヒマシ油からなるエマルショ ン形切削油剤である ${ }^{26)}$ 。また，クロルブタノールを 0.05 〜 $0.1 \%$ 添加することによってバクテリヤによる切削油 エマルションの劣化を防いだ例むある ${ }^{27)}$ 。レン゙ルシノー ル，トリジオキシメチルニトロメタン $(1,000 \mathrm{ppm})$ な どがエマルション形切削油剤のバクテリヤ抑制に有効と いう報告もある ${ }^{28)}$ 。ニトパラフイン系のバクテリヤ抑 制剂として pseudomonads 硫酸塩還元細菌に有効なも のに，トリス(オキシメチル) ニトロメタン，2-ニトロ -2-エチル-1,3-プロパネジオール・ジプロピオネート, 2 -ニトロ-1-ブタノールなどがある ${ }^{29}$ 。

$2 \cdot 2 \cdot 8$ サビ止メ添加剤を含むエマルション $\left.{ }^{30}, 31\right)$ エマルション形切削油に添加するサビ止メ添加剤として $\mathrm{RO}\left(\mathrm{CR}^{\prime} \mathrm{R}^{\prime \prime}\right)_{m} \mathrm{COOH}$ といら一般式で示されを有機酸類 が有効といら報告がある。Rはアルキル，アリル，アル カリル,アラアルキルなどの基で, $\mathrm{R}^{\prime}$ は $\mathrm{R}^{\prime \prime}$ は $\mathrm{H}$ または アルキル基, $m$ は整数である。たとえば, $n$-テトラデシ ルオキシ酢酸は $20 \sim 500 \mathrm{ppm}$ の添加量で各種のイオン 型あるいはノンイオン型エマルションに添加して良好な サビ止メ性を発揮した。pーノニルフェノキシ酢酸は 200 ppm で著しいサビ止め性を示した ${ }^{30)}$ 。をた塩素を含む 有機化合物, クロルパラフィン, 酸クロリド, クロルア セタールに, 小量の正, 環, オレフィン状不飽和などの
炭化水素または二環式テルペンを添加したものを含む切 削油エマルション，たとえば鉱油に $4 \%$ のクロルパラフ イン (40\% Cl) または過クロルメチルメルカプトクロ ルプロピオン酸エステルを $5 \%$ のジペンテンと混合して 添加しェマルション化したものは，切削油剤として腐食 を生じない ${ }^{311}$ 。

$2 \cdot 2 \cdot 9$ 透明な切削油剤 ${ }^{22)}$ (34) アルカリ金属石油ス ルホネートとリシノレイン酸を配合する $\mathrm{O} / \mathrm{W}$ エマルシ ョンでその組成はペール油（粘度 100 セイボルド秒, $\left.37.7^{\circ} \mathrm{C}\right) 21 \%$, 石油スルホン酸ナトリウム $20.0 \%$, リシ ノレイン酸 $6 \%, \mathrm{Na}_{2} \mathrm{CO}_{3} 1.0 \%, \mathrm{NaOH} 0.6 \%$, ナトリ ウム $o$-フェニルフェノラート $0.3 \%$, 水 $51.1 \%(\mathrm{wt})$ の ものを水で希釈すると透明な油剤として使える ${ }^{32)}$ 。ま た，非イオン界面活性剤を使い，グリコールエーテル 2.5 15\%， ポリオキシェチレンアルキルフェノールエ 一テル (親水性) 1 23\%， ポリオキシエチレンアルキ ルフェノールエーテル（親油性）1～5\%，不水溶性溶媒 50 95\%の配合で透明な切削油剤が作られる ${ }^{33)}$ 。あるい は，炭素原子数が少なくとも 6 個の飽和脂肪族炭化水素 から得られたスルホクロリネート化物 40〜5\% のカル ボン酸スルホアミド塩の水溶液を 20 倍の水で薄めて澄 明な油剤をうるが，この油剤はサビ止メ性も良好であ る34。

$2 \cdot 2 \cdot 10$ アルキロールアミンを主剤とする切削液 $\left.{ }^{35)}, 36\right)$ 脂肪酸のアルキロールアミド(N-ステロイルエタ)ール アミド)，アルキロールアミン塩 (トリエタノールアミ ン・ステアレート), ポリアルキルポリアミン（モノス テアロイル・ジェチレンテトラミン) などから選び, これに $\mathrm{K}_{2} \mathrm{CrO}_{4}, \mathrm{NaNO}_{2}$, リン酸塩などを加えた切削油 剤である。配合例として, オレイン酸 $0.3 \sim 0.9 \%(\mathrm{wt})$, ジイソプロパノールアミン $0.24 \sim 0.75 \%, \quad \mathrm{~N}, \mathrm{~N}$-ビス (2-オキシプロピル) オレアミド $0.15 \sim 0.45 \%$ ， $\mathrm{K}_{2} \mathrm{CrO}_{4} \quad 0.05 \sim 0.15 \%$, 残りは水で $97.75 \sim 99.26 \%$ が ある ${ }^{35)}$ 。アミンを主剈とするソリューション形の配合例 では, トリエタノールアミン $5 \%, \mathrm{CaCl}_{2} 2 \%, \mathrm{NaCO}_{2}$ $1 \%$,グリセリン $1 \%$, ヘキサメタリン酸ナトリウム $2 \%$ ，湿潤剤 OP-7 0.5\%，残りは水といら例がある ${ }^{36)}$ 。

以上の資料は，主として諸外国の特許に現われた最近 の切削, 研削油剤の配合例を紹介したもので, 先にあげ た JIS の分類に合うわけではないが，最近の油剤組成が どのような形のものかを，一部知る手がかりになるもの と思い記載したものである。

\section{3 切削・研削油剤の試験とその問題点}

切削油剤の化学成分の試験項目は前述の JIS にも規定 されており, 不水溶性切削油剤の試験方法と項目は, 試 料採取方法, 脂肪油分, イオウ分よびび塩素分, 動粘度 
引火点, 水分, 流動点, 腐食試験があり, 水溶性切削油 剂の試験方法と項目は, 試料採取方法, 表面張力, 乳化 安定度試験, 比重測定方法, 反応試験法, アワ立于試 験，腐食試験，不揮発分試験方法がある。これらの個々 の項目は，配合された油剤成分の試験としてそれなりの 意味があるが，元来ある配合が実用上良いと判断される 根拠はごのような性能判定試験によって行なわれたのか といらことになると JIS の現状には問題が残っている。

JIS-K-2241 には, 「性能判定試験 は実験室的規模が 望ましく，小規模な実験で切削油剤の評価ができればこ れに越したことはない。元来切削油剤の効果は, 潤滑作 用, 冷却作用掠よび反融着作用, 浸潤作用, 洗浄作用な どの総合的な作用効果であると考えられ，これらの諸作 用のらち, ある因子の効果だけ調べても, 全体としての 効果を知るには至らない。また一工作機械での害用試験 結果を他種工作機械へ適用した場合, 必ずしも良好な効 果を保証するとは限らない。すなわち, 機械の種類, 被 加工物の種類, 工具の種類などの条件が変化することに より，同一の切削油剤は同じ効果を発揮するとはかぎら ない。また実験室的な機械的評価法を実施することも困 難な問題が山積しており, 普遍的に認容されている試験 方法がないと考えられたことから，今回は性能判定試験 方法を採用するに至らかった。な抬参考として従来行な われている各種性能判定試験方法をつぎに例示する」と いって，1）切削, 研削機またはその機構を用いる試験 方法 (現場的方法)：i）切削温度を測定する方法, ii) 切削力を測定する方法, iii) 工具刃先の消耗長を測定 する方法，iv）仕上面あらさを測定する方法，v）穴 あけ個数によって判定するドリル寿命試験， vi）放射 性物質を用いる方法，vii）研削量を測定する方法， viii） 研削温度を測定する方法，ix） 研削力を測定す る方法， x） 切り残し量を測定する方法， xi） その他 各種，2）直接切りクズを出さない試験方法：i） 四球 式油試験機，ii）振子形摩擦試験機，iii）チムケン試 験機，iv）処女面摩擦試験機，v） その他各種——を げている。これについては著者はいささかの反論がある。 たとえば，図-1 に示すよらに油剤性能に関与する要因 は実に多数のものがあるが，推計学的発想法からい觉 ば，JIS．にいらような「機械的評価法を実施するにも困 難な問題が山積している」と考えて手をつかねてしまう 代わりに，積極的に JIS 制定に関与した学識経験者や油 剤会社の研究者が，性能判定試験法の採択と検討につい ての共同実験を行ならべきではなからうか。とくにこの ような「性能判定試験法の標準化の研究」には, 推計学 的発想が必要で, 各研究機関, 会社, 油剤メーカが統計 的に要因実験を計画し共同研究を行なえば，おそらく筋 の通った性能判定試験のいくつかを規格化することがで きるであろう。著者がこの点につき指摘したのは古く 1963 年切削油剤の JIS 設定の記念講演会の席上で ${ }^{38)}$, そ の後の経過からっごく一部の研究者が基礎的段階の仕事 にこの発想を活用しているが37)，必ずしも発展している わけではない。

また，切削の場合，切削工具とくにバイトが超硬バイ トになると油剤を使わなくてもよく，油剂を使うのは八 イスに限局されることや，将来精密鋮造が発達してむだ な切りクズを出す切削が次第に少なくなり，すぐ仕上げ のための研削だけですむ時期が来ることも考えられる。 そのような場合は，主として界面活性剤を利用した水溶

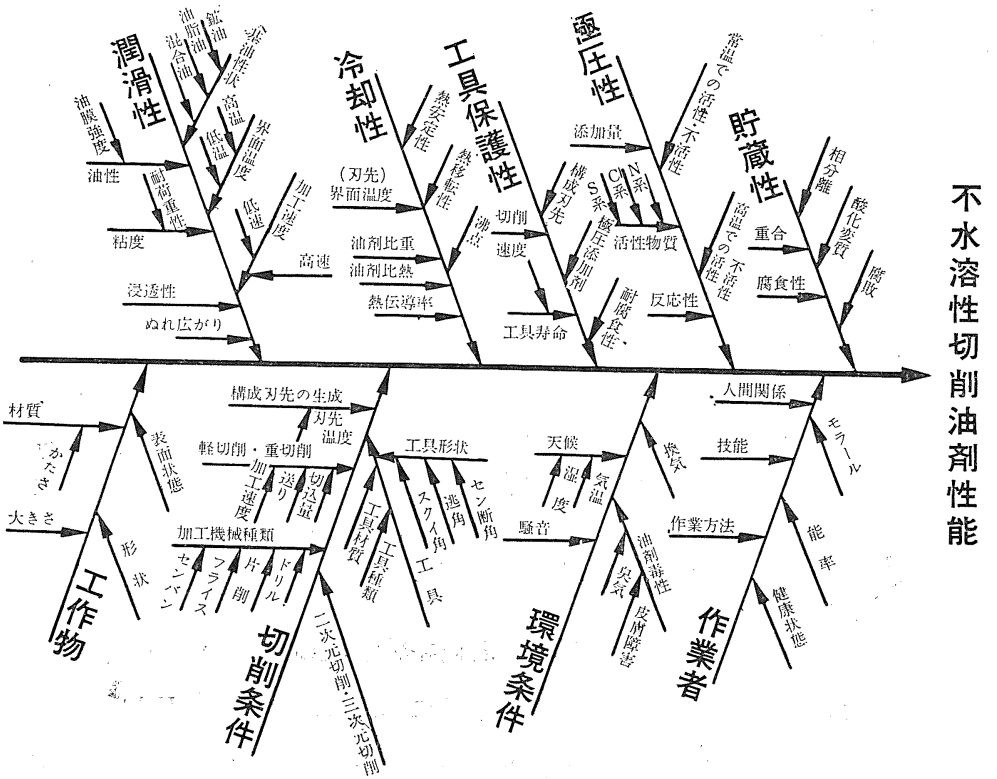

図-1 不水溶性切削油剂性能判定における特性要因図 性研削油剤の活用はさらに問題に されるであるらし，研削油剤の挙 動や性能判定試験法が問題になる と思う。もちろん切削も研削もこ れまで性能判定試験の実験的研究 が数多く行なわれているが，いわ ゆる情報の限局性が問題なのであ って，著者が指摘するのは「性能 判定試験法の標準化」のために共 同実験の発想吕必要であるという ことである。

ところで,著者の研究室では,こ れまで性能判定試験法の標準化」 のために基礎研究を行なってきた ので，その一部をここに紹介し， 化学成分の試験項目 では差異が あっても実用性能試験ではその差 異が判定できなかったり, 実験計 画法を応用して各種の要因を比較 


\section{实 験 資 料}

（1）ドリングによる切削油剤性能試験の一例 $\mathrm{L}_{16}\left(2^{15}\right)$ 型直交表 ${ }^{39}$ によるドリリングの要因実験

\begin{tabular}{|c|c|c|c|}
\hline 因 子 & 水準 & 内 & $\mid \begin{array}{l}\text { ワリツ } \\
\text { ケの列 }\end{array}$ \\
\hline \multirow[t]{2}{*}{ 油 剂 $(\mathrm{O})$} & $\mathrm{O}_{1}$ & 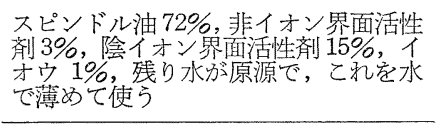 & \multirow[t]{2}{*}{ (15) } \\
\hline & $\mathrm{O}_{2}$ & 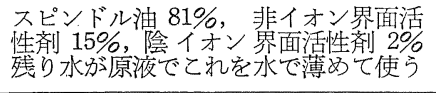 & \\
\hline 希釈率 (D) & $\begin{array}{l}D_{1} \\
D_{2}\end{array}$ & $\begin{array}{l}15 \text { 倍 } \\
30 \text { 倍 }\end{array}$ & (11) \\
\hline 被削材 (M) & $\begin{array}{l}\mathrm{M}_{1} \\
\mathrm{M}_{2}\end{array}$ & 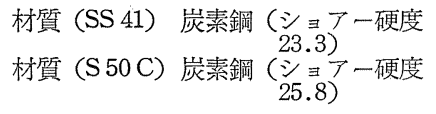 & (10) \\
\hline 回転数 $(R)$ & $\begin{array}{l}\mathrm{R}_{1} \\
\mathrm{R}_{2}\end{array}$ & $\begin{array}{l}650 \mathrm{rpm} \\
1,000 \mathrm{rpm}\end{array}$ & (1) \\
\hline
\end{tabular}

O交互作用: $O \times D(4)$ 列, $O \times M(5)$ 列, $O \times R$ (14) 列

○均一化した実験条伴

○ドリル：直径 $8 \mathrm{~mm}$ ストレートシャンクドリル（SKH 2 JIS-B-4301，理研製)

○荷 重: $5 \mathrm{~kg}$ (バネの反力 $1.4 \mathrm{~kg}$, したがって有效荷重

は $3.6 \mathrm{~kg}$, 定荷重によるドリリング）

○切込量 : $15 \mathrm{~mm}$

○被削材の形状

$32 \phi$ の棒鋼を長さ $30 \mathrm{~mm}$ 亿切り, 切口を研摩平滑化 し, 右図のようにポリ エチレンパイプをから゙ せて「油羿」をつく る。孔の位置にはあら かじめポンチでくぼみ 定つけて和く。その位 置をドリリングする。 ○データ :「データのと 㕫」（注） 油剂だめポリエチレンパイプ

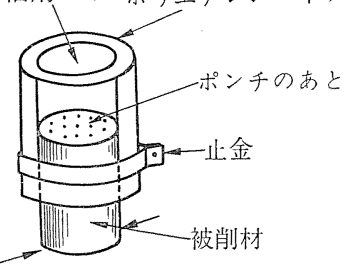

動力計のバイスではさむ

○データ

注） $x_{i}$ 注切削抵抗（荷重 $\left.(\mathrm{kg})\right)$

\begin{tabular}{|c|c|c|c|c|c|}
\hline & $\mid \begin{array}{l}\text { (1) } \\
\text { ドリング所要時間 }\end{array}$ & 卜 & ル ク & スラ & スト \\
\hline 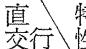 & $\begin{array}{l}15 \text { mmの深さの孔 } \\
\text { をあける要する }\end{array}$ & (2)波 高 & |(3)振 幅 & ${ }^{(4)}$ 波 高 & ${ }^{(5)}$ 振 幅 \\
\hline 番 & 時間它ストップウ & 荷重 $(\mathrm{kg})$ & )荷重 $(\mathrm{kg})$ & 荷重 $(\mathrm{kg})$ & 荷重 $(\mathrm{kg})$ \\
\hline 堂 & オッチで測定 $(\mathrm{sec})$ & $x_{i}$ & $x_{i}$ & $x_{i}$ & $x_{i}$ \\
\hline (1) & 122 & 1.9 & 0.62 & 2.5 & 0.44 \\
\hline+ & 134 & 1.7 & 0.82 & 2.6 & 0.57 \\
\hline$(3)$ & 14 & 2.0 & 0.88 & 2.8 & 0.75 \\
\hline 4) & 149 & 1.5 & 0.74 & 2.8 & 0.44 \\
\hline & & 1.7 & 0.85 & 2.5 & 0.44 \\
\hline 6) & 127 & 1.9 & 0.85 & 2.7 & 0.53 \\
\hline 7) & 15 & 1.6 & 0.97 & 2.6 & 0.62 \\
\hline 85 & 168 & 1.9 & 0.91 & 2.5 & 0.44 \\
\hline (9) & 178 & 1.6 & 0.79 & 2.7 & 0.62 \\
\hline & & 2.1 & 1.0 & 2.7 & \\
\hline (11) & 98 & 1.8 & 0.85 & 2.7 & 0.49 \\
\hline (12) & 147 & 1.6 & 0.9 & 3.0 & 0.57 \\
\hline (13) & & 1.9 & 0.8 & 2.6 & 0.57 \\
\hline & & 1.7 & 1.15 & 2.9 & 0.66 \\
\hline & 111 & 1.8 & 0.8 & 2.8 & 0.49 \\
\hline & 79 & 1.9 & 1.56 & 2.8 & 0.66 \\
\hline
\end{tabular}

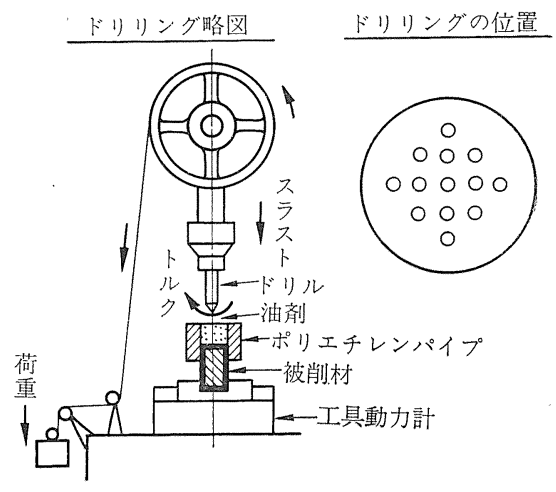

○分散分析表

注) $X_{i}$ : working unit

(1) ドリリング深さ $15 \mathrm{~mm}$ の所要時間 $X_{i}=x_{i}-133$

\begin{tabular}{|c|c|c|c|c|}
\hline 要 因 & 動 & 自由度 & 不偏分散 & 分散比 \\
\hline $\mathrm{R}$ & $3,108.06$ & 1 & $3,108.06$ & 4.67 \\
\hline M & 60.06 & 1 & 60.06 & \\
\hline $\mathrm{D}$ & 390.06 & 1 & 390.06 & \\
\hline $\mathrm{O}$ & $3,937.56$ & 1 & $3,937.56$ & $5.91 *$ \\
\hline $\mathrm{O} \times \mathrm{M}$ & $1,387.56$ & 1 & $1,387.56$ & 2.08 \\
\hline $\mathrm{O} \times \mathrm{R}$ & 915.06 & 1 & 915.06 & 1.37 \\
\hline $\mathrm{e}$ & $5,995.56$ & 9 & 666.17 & \\
\hline 計 & $15,793.93$ & 15 & & \\
\hline
\end{tabular}

(F分布表より)

$F_{9}{ }^{1}(0.05)=5.12 \quad F_{9}{ }^{1}(0.01)=10.56$

$\mathrm{F}_{10}{ }^{1}(0.05)=4.96 \quad \mathrm{~F}_{10}{ }^{1}(0.01)=10.04$

$\mathrm{F}_{11}{ }^{1}(0.05)=4.84 \quad \mathrm{~F}_{11}{ }^{1}(0.01)=9.65$

（2）トルク（波高） $X_{i}=\left(x_{i}-1.8\right) \times 10$

\begin{tabular}{|c|c|c|c|c|}
\hline 要 因 & 変 & 自由度 & 不偏分.散 & 分散比 \\
\hline $\mathrm{R}$ & 0.25 & 1 & 0.25 & \\
\hline M & 4.00 & 1 & 4.00 & $5.71^{*}$ \\
\hline $\mathrm{D}$ & 16.00 & 1 & 16.00 & $22.86^{* *}$ \\
\hline $\mathrm{O}$ & 2.25 & 1 & 2.25 & 3.21 \\
\hline $\mathrm{O} \times \mathrm{R}$ & 12.25 & 1 & 12.25 & $17.50^{* * *}$ \\
\hline $\mathrm{e}$ & 7.00 & 10 & 0.70 & \\
\hline 計 & 41.75 & 15 & & \\
\hline
\end{tabular}

（3） トルク (振幅) $X_{i}=\left(x_{i}-0.92\right) \times 100$

\begin{tabular}{|c|c|c|c|c|}
\hline 要 因 & 変 & 自由度 & 不偏分散 & 分散比 \\
\hline $\mathrm{R}$ & $1,296.00$ & 1 & $1,296.00$ & 2.97 \\
\hline M & 156.25 & 1 & 156.25 & \\
\hline D & 342.25 & 1 & 342.25 & \\
\hline $\mathrm{O}$ & 72.25 & 1 & 72.25 & \\
\hline e & $4,795.25$ & 11 & 435.93 & \\
\hline 計 & $6,662.00$ & 15 & & \\
\hline
\end{tabular}


（4） スラスト (波高) $X_{i}=\left(x_{i}-27\right) \times 10$

\begin{tabular}{|c|c|c|c|c|}
\hline 要 因 & 動 & 自由度 & 不偏分散 & 分散比 \\
\hline $\mathrm{R}$ & 9.00 & 1 & 9.00 & $5.78^{*}$ \\
\hline M & 0.00 & 1 & 0.00 & \\
\hline $\mathrm{D}$ & 0.00 & 1 & 0.00 & \\
\hline $\mathrm{O}$ & 1.00 & 1 & 1.00 & \\
\hline $\mathrm{O} \times \mathrm{D}$ & 4.00 & 1 & 4.00 & 2.56 \\
\hline $\mathrm{O} \times \mathrm{R}$ & 4.00 & 1 & 4.00 & 2.56 \\
\hline $\mathrm{e}$ & 14.00 & 9 & 1.56 & \\
\hline 計 & 32.00 & 15 & & \\
\hline
\end{tabular}

（5） スラスト (振幅) $X_{i}=\left(x_{i}-0.56\right) \times 100$

\begin{tabular}{|c|c|c|c|c|}
\hline 要 因 & 動 & 自由度 & 不偏分散 & 分散比 \\
\hline $\mathrm{R}$ & 182.25 & 1 & 182.25 & 1.66 \\
\hline M & 20.25 & 1 & 20.25 & \\
\hline $\mathrm{D}$ & 0.00 & 1 & 0.00 & \\
\hline $\mathrm{O}$ & 4.00 & 1 & 4.00 & \\
\hline $\mathrm{O} \times \mathrm{M}$ & 240.25 & 1 & 240.25 & 2.19 \\
\hline $\mathrm{e}$ & $1,096.25$ & 10 & 109.63 & \\
\hline 計 & $1,543.00$ & 15 & & \\
\hline
\end{tabular}

○グラフ

(1) ドリリング所要時間

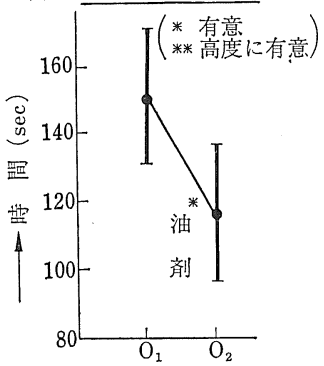

（2）トルク (波高)
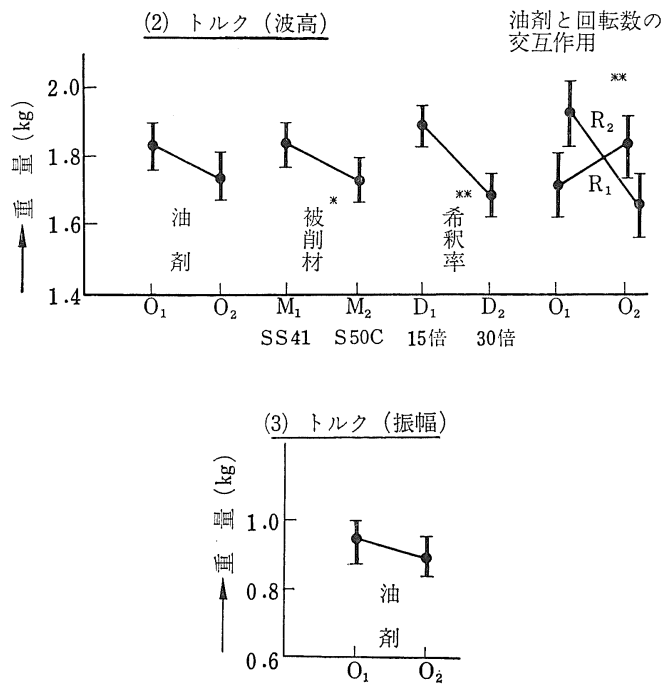

(4) スラスト (波高)
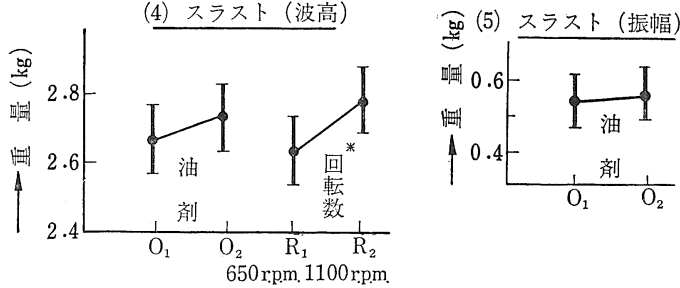

（2）工具動力計を用いた旋盤による切削油剤性能判 定試験の一例

$\mathrm{L}_{16}\left(2^{15}\right)$ 型直交表による切削の要因実験

\begin{tabular}{|c|c|c|c|}
\hline 因 子 & 水準 & 内 & $\begin{array}{l}\text { 割付 } \\
\text { (列) }\end{array}$ \\
\hline 由 剂(O) & $\begin{array}{l}\mathrm{O}_{1} \\
\mathrm{O}_{2}\end{array}$ & $\begin{array}{l}\text { グリセリンにエチレソオキシド・プロ } \\
\text { ピレンオキシド(mol 比 4/3)で } 98 \mathrm{~mol} \\
\text { グリセリンにエチレンオキシド・プロ } \\
\text { ピレンオキシド(mol 比 } 4 / 3) \text { で } 18 \mathrm{~mol}\end{array}$ & (1) \\
\hline 希釈率 (D) & $\begin{array}{l}\mathrm{D}_{1} \\
\mathrm{D}_{2}\end{array}$ & 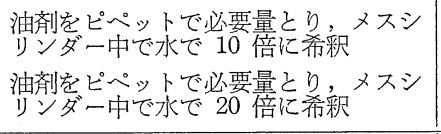 & (2) \\
\hline $\begin{array}{l}\text { バイトの横 } \\
\text { スクイ角 } \\
\text { (B) }\end{array}$ & $\begin{array}{l}\mathrm{B}_{1} \\
\mathrm{~B}_{2}\end{array}$ & $\begin{array}{l}\text { バイトの横スクイ角 } 13^{\circ} \text { (材質 SKH 4) } \\
\text { バイトの横スクイ角 } 15^{\circ} \text { (材質 SKH 4) }\end{array}$ & (5) \\
\hline 被削材 (M) & $\begin{array}{l}\mathrm{M}_{1} \\
\mathrm{M}_{2}\end{array}$ & 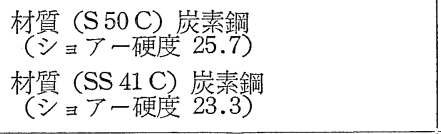 & (12) \\
\hline 回転数 $(R)$ & $\begin{array}{l}\mathrm{R}_{1} \\
\mathrm{R}_{2}\end{array}$ & $\begin{array}{l}610 \mathrm{rpm} \\
486 \mathrm{rpm}\end{array}$ & $(6)$ \\
\hline 切込及量 & $\begin{array}{l}\mathrm{C}_{1} \\
\mathrm{C}_{2}\end{array}$ & $\begin{array}{cc}\text { 切込み量 } & 1.5 \mathrm{~mm} \\
\prime \prime & 2.5 \mathrm{~mm}\end{array}$ & $(8)$ \\
\hline 送り量 $(\mathrm{S})$ & $\begin{array}{l}\mathrm{S}_{1} \\
\mathrm{~S}_{2}\end{array}$ & $\begin{array}{cr}\text { 自動送りの速さ } 0.26 \mathrm{~mm} / \mathrm{rev} \\
\text { " } \quad 0.34 \mathrm{~mm} / \mathrm{rev}\end{array}$ & (10) \\
\hline
\end{tabular}

○交互作用の割付 $\mathrm{O} \times \mathrm{R}(7) ; \mathrm{O} \times \mathrm{C}(9) ; \mathrm{D} \times \mathrm{M}(14) ; \mathrm{B} \times \mathrm{R}$ (3)

○パイトの形状: 前スクイ角 $8^{\circ}$, 前逃げ角 $7^{\circ}$, 横スクイ角 は因子 B，横逃げ角 $7^{\circ}$

○データ

注） $x_{i}$ :オッシログラフから求めた切削抵抗 (荷重 $(\mathrm{kg})$ )

\begin{tabular}{|c|c|c|c|c|c|c|}
\hline \multirow[b]{2}{*}{ 塞番 } & \multicolumn{2}{|c|}{ 主 分 力 } & \multicolumn{2}{|c|}{ 送り分力 } & \multicolumn{2}{|c|}{ 背 分 力 } \\
\hline & $\begin{array}{c}\text { 波 }{ }^{\text {高 }} \\
x_{i}\end{array}$ & $\begin{array}{c}\text { 振 }{ }_{x_{i}} \text { 幅 } \\
\end{array}$ & 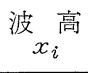 & ${ }^{\text {振 }} x_{i}{ }^{\text {幅 }}$ & 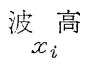 & $\begin{array}{c}\text { 振 }{ }_{x_{i}} \text { 幅 } \\
\end{array}$ \\
\hline 1 & 19 & 5 & 7 & 2 & 8 & 2 \\
\hline 2 & 48 & 10 & 25 & 8 & 18 & 5 \\
\hline 3 & 18 & 5 & 6 & 2 & 4 & 2 \\
\hline 4 & 61 & 29 & 26 & 13 & 10 & 7 \\
\hline 5 & 30 & 8 & 12 & 8 & 16 & 9 \\
\hline 6 & 32 & 7 & 13 & 3 & 9 & 3 \\
\hline 7 & 25 & 7 & 11 & 4 & 4 & 2 \\
\hline 8 & 49 & 13 & 20 & 8 & 10 & 4 \\
\hline 9 & 24 & 12 & 10 & 6 & 7 & 4 \\
\hline 10 & 51 & 14 & 25 & 8 & 9 & 4 \\
\hline 11 & 19 & 6 & 7 & 3 & 8 & 3 \\
\hline 12 & 51 & 16 & 23 & 11 & 18 & 8 \\
\hline 13 & 58 & 31 & 26 & 15 & 10 & 7 \\
\hline 14 & 32 & 12 & 12 & 4 & 4 & 2 \\
\hline 15 & 28 & 6 & 14 & 5 & 9 & 3 \\
\hline 16 & 30 & 7 & 12 & 3 & 11 & 2 \\
\hline
\end{tabular}


○分散分析表 注) $X_{i}:$ Working unit

(1) 主分力 (波高) $X_{i}=x_{i}-36$

\begin{tabular}{|c|c|c|c|c|}
\hline 要 因 & 変 & 自由度 & 不偏分散 & 分散比 \\
\hline $\mathrm{O}$ & 7.56 & 1 & 7.56 & \\
\hline $\mathrm{D}$ & 3.06 & 1 & 3.06 & \\
\hline B & 232.56 & 1 & 232.56 & $9.59 *$ \\
\hline M & 297.56 & 1 & 297.56 & $12.27^{*}$ \\
\hline $\mathrm{R}$ & 45.56 & 1 & 45.56 & \\
\hline $\mathrm{C}$ & $1,105.56$ & 1 & $1,105.56$ & $45.57^{* *}$ \\
\hline $\mathrm{S}$ & $1,040.06$ & 1 & $1,040.06$ & $42.87^{* *}$ \\
\hline $\mathrm{O} \times \mathrm{R}$ & 45.56 & 1 & 45.56 & \\
\hline $\mathrm{O} \times \mathrm{C}$ & 248.06 & 1 & 248.06 & $10.23 *$ \\
\hline $\mathrm{D} \times \mathrm{M}$ & 60.06 & 1 & 60.06 & \\
\hline $\mathrm{e}$ & 121.31 & 5 & 24.26 & \\
\hline 計 & $3,206.91$ & 15 & & \\
\hline
\end{tabular}

（3）送分力（波高）

\begin{tabular}{|c|c|c|c|c|}
\hline 要 因 & 変 & 自由度 & 不偏分散 & 分散比 \\
\hline $\mathrm{O}$ & 5.06 & 1 & 5.06 & \\
\hline $\mathrm{D}$ & 5.06 & 1 & 5.06 & \\
\hline B & 33.06 & 1 & 33.06 & 4.68 \\
\hline M & 33.06 & 1 & 33.06 & 4.68 \\
\hline $\mathrm{R}$ & 0.06 & 1 & 0.06 & \\
\hline $\mathrm{C}$ & 248.06 & 1 & 248.06 & $35.14^{* *}$ \\
\hline $\mathrm{S}$ & 351.56 & 1 & 351.56 & $49.79 * *$ \\
\hline $\mathrm{O} \times \mathrm{R}$ & 10.56 & 1 & 10.56 & \\
\hline $\mathrm{O} \times \mathrm{C}$ & 68.06 & 1 & 68.06 & $9.64^{*}$ \\
\hline $\mathrm{D} \times \mathrm{M}$ & 18.06 & 1 & 18.06 & \\
\hline e & 35.31 & 5 & 7.06 & \\
\hline 計 & 807.91 & 15 & & \\
\hline
\end{tabular}

(5) 背分力 (波高)

\begin{tabular}{|c|c|c|c|c|}
\hline 要 因 & 変 動 & 自由度 & 不偏分散 & 分散比 \\
\hline $\mathrm{O}$ & 0.56 & 1 & 0.56 & \\
\hline $\mathrm{D}$ & 5.06 & 1 & 5.06 & \\
\hline B & 95.06 & 1 & 95.06 & $20.85^{* *}$ \\
\hline M & 39.06 & 1 & 39.06 & $8.57^{*}$ \\
\hline $\mathrm{R}$ & 0.56 & 1 & 0.56 & \\
\hline $\mathrm{C}$ & 33.06 & 1 & 33.06 & $7.25^{*}$ \\
\hline $\mathrm{S}$ & 68.06 & 1 & 68.06 & $14.93^{* *}$ \\
\hline $\mathrm{D} \times \mathrm{M}$ & 18.06 & 1 & 18.06 & 3.96 \\
\hline $\mathrm{e}$ & 31.93 & 7 & 4.56 & \\
\hline 計 & 291.43 & 15 & & \\
\hline
\end{tabular}

- $\mathrm{F}_{5}{ }^{1}(0.05)=6.61$, $\mathrm{F}_{5}$

$\mathrm{F}_{7}{ }^{1}(0.01)=12.25$

○グラフ

\section{(1) 主分力 (波高)}

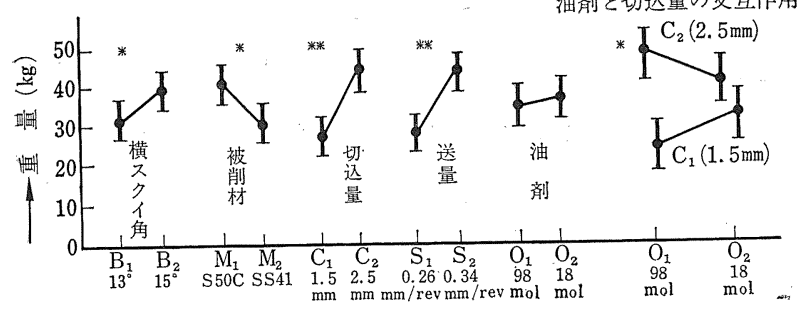

（注）工具動力計オッシロ （2）主分力（振幅）

要 因|変 動 |自由度| 不偏分散| 分散比

\begin{tabular}{c|r|r|r|r}
$\mathrm{O}$ & 25.00 & 1 & 25.00 & \\
$\mathrm{D}$ & 2.25 & 1 & 2.25 & \\
$\mathrm{~B}$ & 210.25 & 1 & 210.25 & $23.47^{* *}$ \\
$\mathrm{M}$ & 182.25 & 1 & 182.25 & $20.34^{* *}$ \\
$\mathrm{R}$ & 100.00 & 1 & 100.00 & $11.16^{*}$ \\
$\mathrm{C}$ & 49.00 & 1 & 49.00 & $5.47^{*}$ \\
$\mathrm{~S}$ & 182.25 & 1 & 182.26 & $20.34^{* *}$ \\
$\mathrm{O} \times \mathrm{C}$ & 100.00 & 1 & 100.00 & $11.16^{*}$ \\
$\mathrm{~B} \times \mathrm{R}$ & 30.25 & 1 & 30.25 & \\
$\mathrm{e}$ & 53.75 & 6 & 8.96 & \\
\hline 計 & 935.00 & 15 & & \\
\hline
\end{tabular}

（4）送分力（振幅）

要 因 $\mid$ 变 動 $\mid$ 自由度 $\mid$ 不偏分散 $\mid$ 分散比

\begin{tabular}{l|l|l|l}
$\mathrm{O}$ & 3.06 & 1 & 3.06
\end{tabular}

\begin{tabular}{l|l|l|l}
$\mathrm{D}$ & 0.56 & 1 & 0.56
\end{tabular}

\begin{tabular}{l|r|r|r}
$\mathrm{D}$ & 0.56 & 1 & 0.56 \\
$\mathrm{~B}$ & 18.06 & 1 & 18.06
\end{tabular}

M

52.56

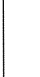

52.56

\begin{tabular}{l|l|l|l}
$\mathrm{R}$ & 14.06 & 1 & 14.06 \\
\hline
\end{tabular}

\begin{tabular}{l|l|l|l}
$\mathrm{C}$ & 10.56 & 1 & 10.56
\end{tabular}

\begin{tabular}{l|r|r|r}
$\mathrm{S}$ & 105.06 & 1 & 105.06
\end{tabular}

\begin{tabular}{l|l|l|r}
$\mathrm{O} \times \mathrm{R}$ & 3.06 & 1 & 3.06
\end{tabular}

\begin{tabular}{l|l|l|l}
$\mathrm{O} \times \mathrm{C}$ & 22.56 & 1 & 22.56
\end{tabular}

\begin{tabular}{l|l|l|l}
$\mathrm{D} \times \mathrm{M}$ & 3.06 & 1 & 3.06
\end{tabular}

\begin{tabular}{c|r|r|r|l}
$\mathrm{e}$ & 3.31 & 5 & 0.66 & \\
\hline 計 & 235.91 & 15 & & \\
\hline
\end{tabular}

(6) 背分力 (振幅)

要 因 $\mid$ 変 動 $\mid$ 自由度 $\mid$ 不偏分散 $\mid$ 分散比

$27.36^{* * *}$

$79.64^{* *}$

$21.30^{* *}$

$16.00 *$

$159.18^{* *}$

$34.18^{*}$

\begin{tabular}{l|l|l|l|l}
$\mathrm{O}$ & 0.06 & 1 & 0.06 & \\
$\mathrm{D}$ & 0.56 & 1 & 0.56 &
\end{tabular}

\begin{tabular}{l|l|l|l}
$\mathrm{B}$ & 0.56 & 1 & 0.56
\end{tabular}

$\mathrm{M}$

$\mathrm{R}$

22.56

0.56

22.56

14.06

$19.96^{* *}$

$12.42 * *$

0.56

\begin{tabular}{r|r|r}
33.06 & 1 & 33.06 \\
3.06 & 1 & 3.06
\end{tabular}

$\mathrm{B} \times \mathrm{R}$

7.93

82.43

1.13

$29.26^{* *}$

$=5.99, \mathrm{~F}_{6}{ }^{1}(0.01)=13.75, \mathrm{~F}_{7}{ }^{1}(0.05)=5.59$,

一 \\ 一}

やムシレ形切クズの発生など

を意味し, バイトの取付け具 合, センター割り出しの良し悪し, スクイ角の良し悪し などを意味する量として技術的に解釈することもでき る。

すると技術的に意味の出てくる因子の格付けが異 なったりする事実を指摘し, 今後の実用性能試験 法開発の参考に供したい( ${ }^{38) 。 ~}$

ここでは，ドリリングによる切削油剤性能判定 試験の一例と旋盤による性能判定試験の一例を紹 
(2) 主 分力（振幅）

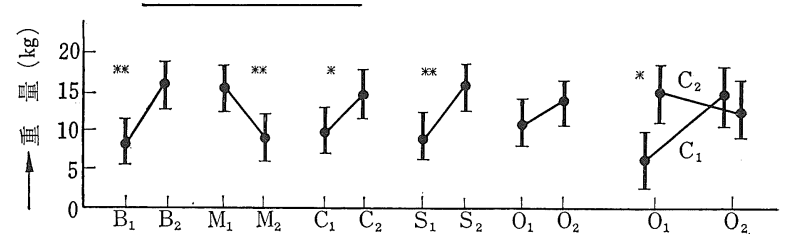

（3）送分力（波高）

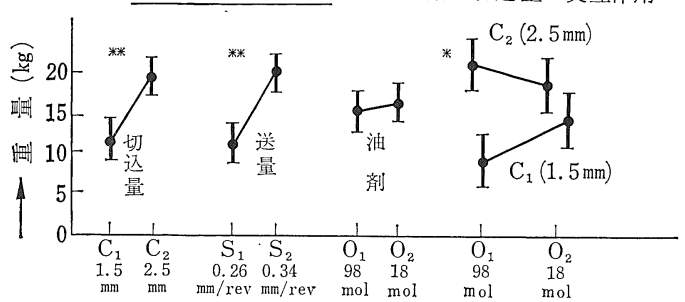

(4) 送分力 (振幅)

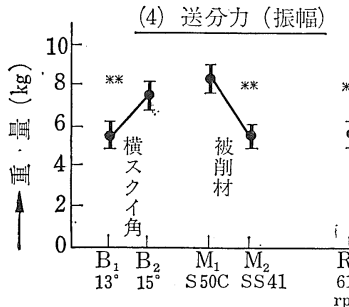

(5) 背分力 (波高)

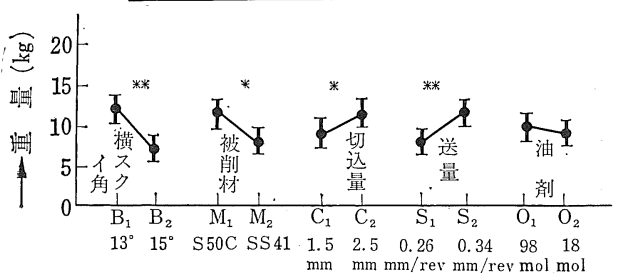

(6) 背 分力.(振幅)

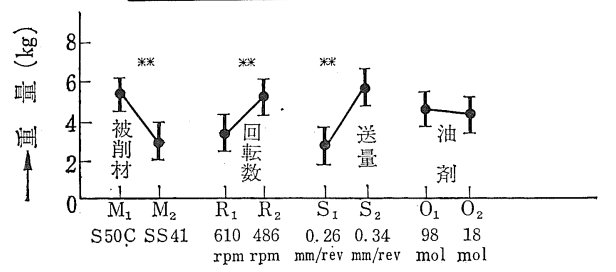

介する。いずれも化学者がその配合を工夫し， 化学成分試験項目や振子形摩擦試験などの範囲 では著しい差異のあった油剤配合のものを実用 的性能判定試験にかけてみたわけである（供試 物質名は提供者の事情により省略)。

油剤以外にドリリングや旋盤加工に必要な条 件の諸因子をいくつか採りあげ，直交配列表に より実験計画と割付を行ない実験し ${ }^{39)}$ ，その結 果について要因分析を行なった。

ドリリングの例では，「15 mm の孔をあける

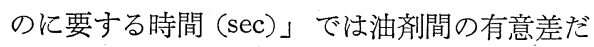

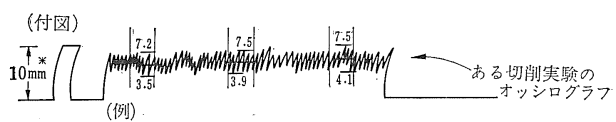

(波高: $\frac{7.2+3.5}{2}=5.4, \frac{7.5+3.9}{2}=5.7, \frac{7.5+4.1}{2}=5.8$ (平均 5.6 )

$\{$ 振 幅: $7.2-3.5=3.7,7.5-3.9=3.6, \quad 7.5-4.1=3.4$ (平均 3.6 )

けを求めることができたが，同時に測定した 切削抵抗のトルクやスラストをオッシログラ フから調べても油剤因子の差は求められず希 釈率, 被削材質, 回転数などの因子が有意と なっていて，採りあげた特性值によって情報 が異なったことがわかった (写真参照)。旋盤 加工の例でも, 主分力, 脊分力, 送り分力な ぞの切削抵抗をオッシログラフにかけて求め てタ，配合した界面活性剂の差は得られず, もっぱら機械加工の条件因子にだけいくつか 有意差が出た。実験室で，化学成分試験項目 や一部の物性試験で求まっていた界面活性剤 の差異は，実用試験にかけるとその相関が求 まらず，油剂間の性能の差異を証明できない 状態で終ってしまらことがあるといらことで ある。もちろん，統計的に有意差なしといら ことの原因には，採りあげた機械加工の条件 因子の適，不適，実験の繰り返し数の不足，実験誤差の 大きさ, 試験法もしくは特性值の優劣あるいは感度な ど，いろいろ考慮の余地はあろら。ただ，ここにかかげ た実験の程度のものでも，過去にもうと実験計画法を使 った実地試験の例が積み重ねられ，情報として利用され ていればともかく，切削や研削の過去の実験例のほとん どが，特定条件の下でのみ成り立つような情報しか提供 してくれていないので，今後なお改めて実用的な油剤性

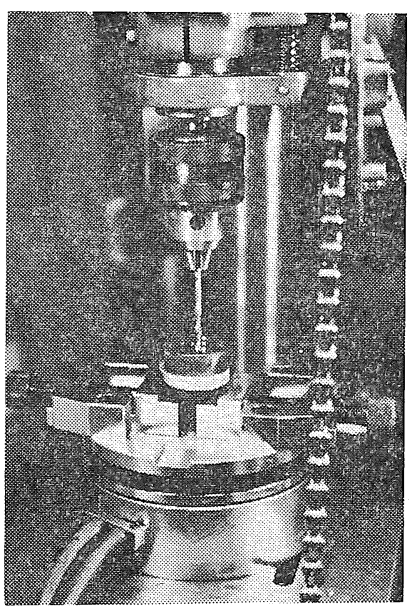

写真-1 ドリリング用工具動力計お よび試験片の接写 (著者の 使用している設備)

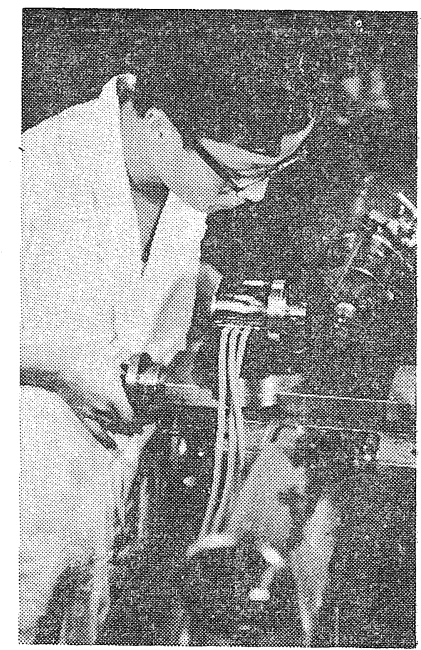

写真-2 工具動力計を用いた切削と 切削抵抗三分力のオッシロ グラフよる自記記録 


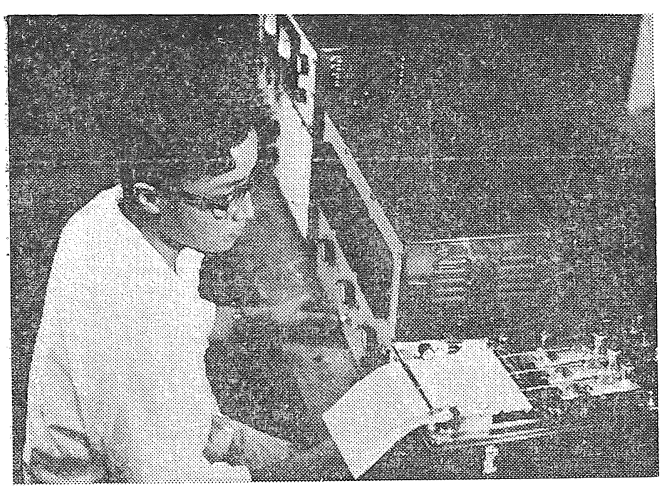

写真-3 工具動計を用いた切削と切削抵抗三分力のオッシ ログラフによる自記記録

能判定試験法の標準化のための要因実験を試みる必要が ある。とくに前述の JIS にもあるように,すでにいくつ もの試験法や特性值が知られ，使われてはいるが，試験 法の優劣や感度の比較, 情報量の検討についてはまだ充 分な比較検討が行なわれていると思えないし，これらの 仕事は多くの研究者が共同で進めてはじめて成果のあが る地味ではあるが価值のある仕事と考えるものである。

\section{4 あとがき}

切削, 研削油剂への界面活性剤の応用は今後に幾多の 研究を残している。化学者にとつては, 機械加工の害用 領域を手かけることはとかく境界領域の仕事になり，泥 沼に足を入れて動きがとれないおそれもあるが，実用上 の裏付けと油剤配合の根拠を与える試験法を持たずに実 験室測度からの情報だけで配合を工夫しても，現場の使 用に際して効果が不明なものとなってしまうお去れがあ る。関係方面の研究者の再検討を願う次第である。

(昭和 44 年 5 月 20 日受理)

\section{文献}

1) F.I. Mandich, U.S.S.R., 218,364 (17, May, 1968)

2) John, H.J. Tarazi et al., U.S., 3,309,315 (March. 14, 1967)

3) Joseph, A. Smith., U.S.,, 2,814,594 (Nov. 26, 1957)

4) Jacobs Rinse., U.S., 2,829,101 (Apr. 1, 1958)

5) David Frazier, U.S., 2,706,176 (Apr. 12, 1955)

6) Everett, C. Hughes et al., U.S., 2,790,773 (1955)

7) Max. Zimmermann, et al., Ger., 928,194 (May. 26,
1955)

8) Max. Zimmermann et al., Ger. 865,039 (Jan. 29, 1953)

9) Amos. Dorinson, U.S., 2,771, 423 (Nov. 20, 1956)

10) Everett C. Hughes et al., U.S., 2,852,468 (Sept. 16, 1958)

11) Amos. Dorinson, U.S., 2,711,395 (June 21, 1955)

12) Michael, G. Billett et al., Belg. 626,287 (Apr. 15, 1963)

13) Richard, J. Westland et al., Brit., 950,069 (Feb. 19, 1964)

14) Société les émulgateurs industriels, S.àr.l. Fr. 1,001,383 (Feb. 22, 1952)

15) Ming Feng, U.S., 2,918, 432 (Dec. 22, 1959)

16) Takitaka, Shiba et al., Japan, 285 (Jan. 20, 1956)

17) Frederick, E. Tice., U.S., 3,287,268 (Nov. 22, 1966)

18) Geo, R. Cook et al., U.S., 2,764,549 (Sept. 25, 1956)

19) Laurence, F. King et al., U.S., 2,695,272 (Nov. 23, 1954)

20) N.V. de Batsafsche, Petroleum Maatschappij, Dutch. 80,211 (Jan. 16, 1956)

21) John D. Oathout, U.S., 2,802,786 (Aug. 13, 1957)

22) Charles, H. Benton, Jr., Brit., 1,025,240 (Apr. 6, 1966)

23) Vaughn, Robert, L., U.S., 3,388,062 (Jun. 11, 1968)

24) James, K. Jacques, Brit., 1,064,758 (Apr. 12, 1967)

25) Paul, B.H. Robinson, Brit., 1,043,392 (Step. 21, 1966)

26) Rudolf, Vlasak et al., Prac. Lek, 19 (4), 167-72 (1967)

27) Robert, F. Holmes, Australian, 258,684 (Apr. 21, 1965)

28) Hebe, L. Martelli, Quimica, No. 38, 4-5 (1960)

29) E.O. Bennett et al., Lubsication Eng., 16, 228-30 (1960); Appl. Micrbial, 7, 117-21 (1959); ibid., 4, 122-6 (1956) etc

30) Michael Taylor, Ger., 1,224,584 (Sept. 8, 1966)

31) Adolf Hrubesch, Ger., 1,006,694 (Apr. 18, 1957)

32) N.V. de Bataafsche, Petroleum Maatschappij, Brit., 821, 495 (Oct. 7, 1959)

33) James, R. Alburger, U.S., 3,282,843 (Nov. 1, 1966)

34) Ludwig Orthner, et al., Ger. 952,927 (Nov. 22, 1956)

35) Mario Bellucco, Ital. 513,091 (Feb. 3, 1955)

36) N.P. Lukin et al., U.S.S.R., 116, 464 (Jan. 19, 1959)

37）奥島，人見，棚橋，日本機械学会論文集，33，1869-75; 同誌, 1876-83, (1967)

38）後藤，金属表面技術，15，74-80 (1964); “界面活性剂の 工業的応用講習会テキスト” p. 7-1 7-29 (1965) 日刊 工業新聞社

39）田口，“実験計画法”（上)，丸善 